\title{
Reducing Nitrate Accumulation and Fertilizer Use in Lettuce with Modified Intermittent Nutrient Film Technique (NFT) System
}

\author{
Vincenzo Tabaglio*(D), Roberta Boselli, Andrea Fiorini, Cristina Ganimede, Paolo Beccari, \\ Stefano Santelli and Giuseppe Nervo
}

Department of Sustainable Crop Production, Università Cattolica del Sacro Cuore, Via Emilia Parmense 84, 29122 Piacenza, Italy; roberta.boselli@unicatt.it (R.B.); andrea.fiorini@unicatt.it (A.F.); cridott86@gmail.com (C.G.); paolo89.beccari@gmail.com (P.B.); stefano.santelli@unicatt.it (S.S.); giuseppe.nervo@unicatt.it (G.N.)

* Correspondence: vincenzo.tabaglio@unicatt.it; Tel.: +39-0523-599222

Received: 16 July 2020; Accepted: 14 August 2020; Published: 17 August 2020

\begin{abstract}
Lettuce (Lactuca sativa L.) is a leading greenhouse-grown vegetable. However, nitrate $\left(\mathrm{NO}_{3}{ }^{-}\right)$accumulation in leaves remains a major issue. The aims of this research were: (i) to test the modified intermittent Nutrient Film Technique (NFT) in the cultivation of soilless lettuce in which plants are grown on peat blocks in trays and supplied with an intermittent flow of nutrient solution, and (ii) to calibrate the fertilization scheme to increase yield performance, while keeping $\mathrm{NO}_{3}{ }^{-}$concentration under control. Two greenhouse trials were performed between autumn 2013 and spring 2014. Results showed that a 30-day cycle is the optimum duration in terms of fresh biomass yield, both for autumn and spring cultivation. Reducing $\mathrm{N}$ fertilization in the last cropping days never affected $\mathrm{NO}_{3}{ }^{-}$concentration in leaves during autumn trial, due to unfavourable growing conditions. Conversely, suspension of fertilization 2 days before harvest had a consistent effect during the spring trial, when $\mathrm{NO}_{3}{ }^{-}$concentration in leaves was highly reduced (from 20 to 36\%) without yield penalties. Thus, suspending fertilization $2-4$ days before harvesting in intermittent NFT may reduce, on average, $\mathrm{NO}_{3}{ }^{-}$accumulation by $29-58 \%$ and the fertilization rate by $7-16 \%$, respectively. Yet, growing conditions are crucial to make this system effective.
\end{abstract}

Keywords: food safety; lettuce; nitrates; soilless cropping system

\section{Introduction}

Lettuce (Lactuca sativa L.) is a widely cultivated leafy vegetable belonging to the Asteraceae family. Lettuce is one of the main greenhouse-grown vegetables, being recognized as highly productive and economically valuable [1]. As reported by FAOSTAT [2], world production of lettuce and chicory consists of around $27 \mathrm{Mt}, 73.7 \%$ of which is produced in Asia and 9.7\% in Europe. Cultivation of lettuce and chicory in Italy covers around 34,460 ha and yields an annual production of 768,055 t. Leafy Lettuce (L. sativa, var. acephala) is very important among fresh-cut, minimally processed vegetables, increasingly requested for fast-food, catering and home consumption [3]. Due to its content in terms of vitamins, minerals and biologically active compounds such as photosynthetic pigments and phenols, lettuce has also been recognized as an important functional food [4].

However, lettuce also was shown to have sometimes high nitrates concentration in leaves $[5,6]$. Nitrates $\left(\mathrm{NO}_{3}{ }^{-}\right)$per se are relatively nontoxic compounds; yet, around $5-10 \%$ of ingested nitrates are converted to nitrites $\left(\mathrm{NO}_{2}{ }^{-}\right)$in the gastrointestinal tract [7]. Nitrites are highly toxic compounds that can lead to many disorders in humans [7] including blue baby syndrome (methaemoglobinemia in 
infants) as well as other diseases $[8,9]$. For these reasons, the reduction of nitrate intake associated with vegetables consumption in the diet is strongly recommended [10].

Such unfavorable effects derived from $\mathrm{NO}_{3}{ }^{-}$accumulation are highly dependent on environmental and management factors occurring during the cultivation of lettuce [11]. Among these, major drivers are the quality and intensity of light, temperature, and nitrogen availability [12]. Growing leafy vegetables in soilless systems requires careful management of fertilization because of the limited growing substrate and the high density of plants [13]. Optimization of the nutrient solution concentration is required to maximize the yield and quality of lettuce $[14,15]$. When consistent rates of mineral $\mathrm{N}$ are used during the production cycle, especially in a cool climate and with low light intensity, the conversion of $\mathrm{NO}_{3}{ }^{-}$to organic $\mathrm{N}$ pools (i.e., proteins) is restricted and high levels of $\mathrm{NO}_{3}{ }^{-}$could accumulate in lettuce leaves $[12,16]$. Concentration limits of $\mathrm{NO}_{3}{ }^{-}$in lettuce leaves are currently regulated by $\mathrm{EU}$ Reg. No. 1258/2011 [17], according to the period of harvesting and the system of cultivation (Table A1 in the Appendix A).

Beside traditional soil-based production systems, whether in open-field conditions or under protection structures (i.e., greenhouses or tunnels), lettuce is cultivated also in soilless systems (i.e., hydroponics or aquaponics systems). The soilless lettuce is cultivated increasingly in Italy; in 2019, its production may be estimated at around $3000 \mathrm{Mg}$, or about $2 \%$ of total greenhouse lettuce production $(154,465 \mathrm{Mg})$ [18]. Many hydroponic systems have been used in recent years, such as gravel beds, floating systems, and nutrient film techniques [19]. The advantages of using these systems are that they (i) originate in a clean raw material with low microbiological contamination due to reduced contact between leaves and growing substrate [20] and (ii) yield ready-to-use leaf vegetables requiring gentle washing procedures that cause only minimal stress to the leaf tissue [21]. Hydroponic methods are very attractive to growers because they entail lower labor costs than those of conventional soil-based methods. In addition, no weeding is required, and the harvesting is easier and faster than in soil-based cultivation [22].

In recent years, an innovative way to market lettuce and other vegetables has been proposed, consisting in selling entire live plants together with their peat blocks and packaged in a transparent corn-starch bag, thus forming an entirely biodegradable and compostable product. At home, this fresh product can be preserved for a week in a cool, light place, adding water as needed and picking the leaves for immediate consumption. The exhausted bag and peat blocks can be disposed of in household wet waste or in a composter, thus reducing the impact on the environment and lessening the ecological footprint.

To produce lettuce with peat blocks, two main systems are now used. The "Nutrient Film Technique" (NFT) is a hydroponic system in which a thin film of nutrient solution flows continuously over the roots and is then recirculated. Thus, it differs from the "ebb-and-flow" system in which plants cultivated in a growth medium are placed in a tray that is periodically filled with the nutrient solution [23]. An innovative method, intermittent NFT, used in this study, lies midway between the two systems: plants growing on peat blocks are placed in a tray with an intermittent flow of nutrient solution. This intermittence allows greater oxygenation of the root systems and therefore a better health status of the plants.

Nevertheless, these systems require careful fertilization management because of the small amount of the growing substrate per plant [13]. It follows that optimizing nutrient solution concentration and fertilization schedule is a major issue in order to (i) maximize lettuce yield $[14,15]$ and (ii) avoid $\mathrm{NO}_{3}{ }^{-}$ accumulation [10].

The leading objectives of the present study were (a) to identify the optimal growth cycle duration for maximum yield performance in the innovative system of lettuce production (modified intermittent NFT) and (b) to assess the effects of different fertilization strategies under intermittent NFT on nitrate accumulation in lettuce leaves. The initial hypothesis was that reducing the fertilization rate during the last days of the growing cycle would produce a high yield of lettuce and also safe nitrate concentrations in leaves. 


\section{Materials and Methods}

\subsection{Experiment and Treatments}

The experiment was carried out from October 2013 to April 2014 at the Sempre Fresco S.r.l. greenhouse plant located in Guidizzolo, Mantova, Italy (lat. 45.31718 N, long. 10.55832 E), in which an innovative intermittent NFT system has been adopted to produce lettuce laid out and marketed in a new way, potentially more pleasing to consumers. The marketed item consists of a "triple pack" of lettuce plants of three types (Batavia, Romana (cv. longifolia), and Lollo (cv. crispa)) grown in the same block and sold still alive with roots and in their peat block. The weight of the entire package is about $400 \mathrm{~g}$, with $200 \mathrm{~g}$ of edible portion, corresponding to about two servings of mixed salad (Figure 1a).

a)

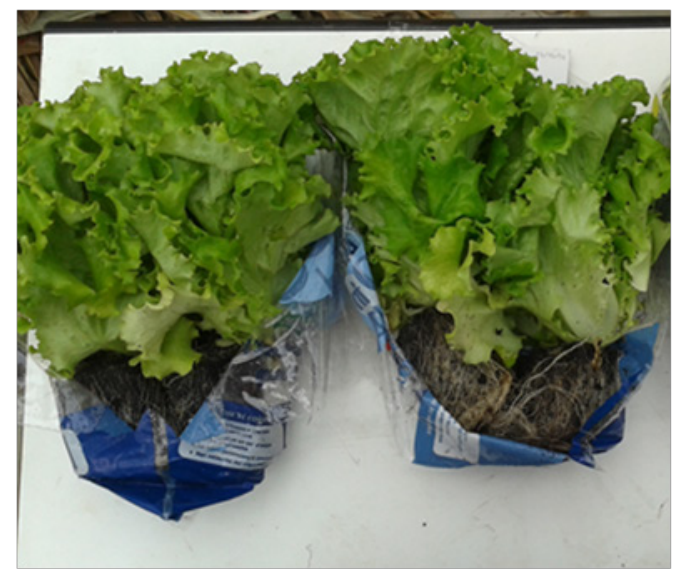

b)

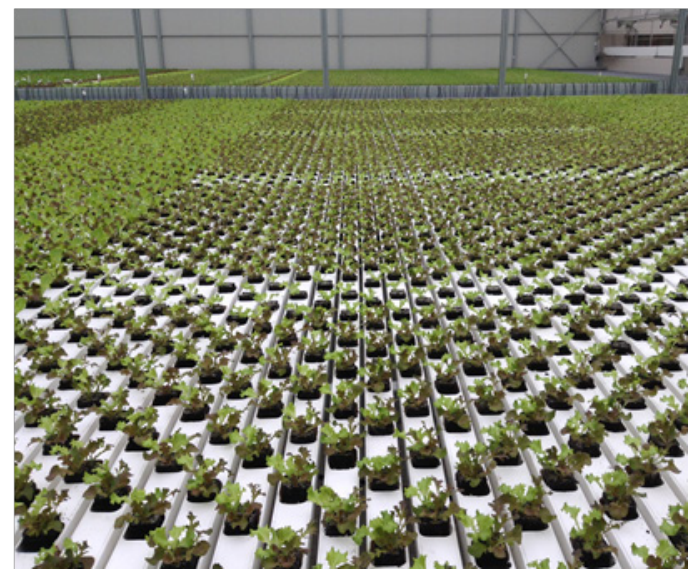

Figure 1. Lettuce triple pack (a) and modified intermittent NFT system for soilless lettuce production at Sempre Fresco ${ }^{\circledR}$ greenhouse (b).

The intermittent NFT system was implemented as follows. The growing cycle was started using approximately 30-day-old seedlings from the nursery in blocks of compressed peat. The blocks with lettuce seedlings having 3-4 leaves each were placed in perforated plastic cable ducts. Each duct was $12.1 \mathrm{~m}$ long, had 57 holes for 57 sticks (Figure $1 \mathrm{~b}$ ), and was placed on a raised surface inclined at a slope of about $3 \%$, thus allowing the water to flow from side to side in the duct. At the beginning of the growing cycle, the ducts with the transplanted seedlings were placed at one end of the greenhouse bench; during the cropping cycle, the ducts were moved automatically to the opposite end of the bench, arriving at the end just in time for harvesting. The ducts were moved by a system of chains located below the bench, which fit into the bottom of the ducts and pushed them forward. The duration of the run was set according to the length of the production cycle, which depends on the season and ranges from 25 to 45 days. At the upper end of each duct there was a tube through which the nutrient solution was fed: the tube entered the slightly sloped duct and ran through it wetting the peat blocks and the lettuce roots. The excess nutrient solution was collected at the bottom of the duct and recycled.

Greenhouse dimensions were $130 \mathrm{~m}$ long, $80 \mathrm{~m}$ wide, and $5 \mathrm{~m}$ high. The framework of the greenhouse consisted of arches of galvanized-iron pipe covered by polyethylene sheeting $0.20 \mathrm{~mm}$ thick. The greenhouse environmental conditions (air temperature and humidity, light intensity) were constantly monitored during the trials from transplanting to harvesting; the $\mathrm{pH}$ of the nutrient solution was maintained within a range from 5.5 to 6.6 and electrical conductivity (EC) ranged from 1.92 to $2.01 \mathrm{mS} \mathrm{cm}^{-1}$.

Using intermittent NFT, we carried out two greenhouse experiments in two different seasons: (1) the autumn trial, performed from 3rd October to 1st November, and (2) the spring trial, from 8th March to 6th April. 


\subsubsection{Autumn Trial}

The autumn elemental experiment was designed as a randomized complete block (RCB) with 4 replicates and 6 treatments, as follows: T1, continuous fertilization; T2, fertilization stopped during the last 2 days; T3, fertilization stopped during the last 4 days; T4, fertilization stopped during the last 6 days; T5, fertilization stopped during the last 8 days; T6, fertilization stopped during the last 10 days. The total number of plots was 24 . Each stick contained one plant of lettuce (cv. Tourbillon, Batavia type). The experiment was repeated six times, investigating the same fertilization scheme for six durations of the growing cycle, from 25 to 30 days after transplanting (DAT).

The two concentrated nutrient solutions (A and B) were stored in two reservoirs with capacity of $1500 \mathrm{~L}$ each, and distributed after dilution. The composition of the concentrated nutrient solutions (A and $\mathrm{B}$ ) is indicated in Table 1 . The diluted nutrient solution had the following physicochemical characteristics: nitrogen concentration $\left(\mathrm{NO}_{3}{ }^{-}+\mathrm{NH}_{4}{ }^{+}\right) 13.8 \mathrm{mmol} \mathrm{L}-1$; $\mathrm{pH} 5.5 ; \mathrm{EC} 2.01 \mathrm{mS} \mathrm{cm}{ }^{-1}$. The fertilization program consisted of 15 irrigations per day, each lasting $3 \mathrm{~min}$, at a flow rate of $0.4 \mathrm{~L} \mathrm{~min}{ }^{-1}$. Each plant received $0.31 \mathrm{~L}$ of water per day. Excess nutrient solution collected from the greenhouse benches was reused after adjustment of $\mathrm{pH}$ and EC and sterilization by UV lamps.

Table 1. Composition of the concentrated nutrient solutions (A and B).

\begin{tabular}{lc}
\hline & Concentrated Nutrient Solution-A \\
\hline Component & Concentration $\left(\mathbf{g ~ L}^{-\mathbf{1}}\right)$ \\
\hline $\mathrm{KNO}_{3}$ & 45.30 \\
$\mathrm{Ca}\left(\mathrm{NO}_{3}\right)_{2}$ & 26.70 \\
$\mathrm{NH}_{4} \mathrm{NO}_{3}$ & 1.33 \\
$\mathrm{Fe}-\mathrm{chelate}(6 \%)$ & 3.00 \\
\hline \multicolumn{2}{c}{ Concentrated Nutrient Solution-B } \\
\hline Component & Concentration $\left(\mathrm{g} \mathrm{L}^{-\mathbf{1}}\right)$ \\
\hline $\mathrm{KH}_{2} \mathrm{PO}_{4}$ & 20.00 \\
$\mathrm{MgSO}_{4}$ & 20.00 \\
$\mathrm{~K}_{2} \mathrm{SO}_{4}$ & 15.30 \\
$\mathrm{KNO}_{3}$ & 14.70 \\
$\mathrm{MnSO}_{4}$ & 0.16 \\
$\mathrm{ZnSO}_{4}$ & 0.23 \\
$\mathrm{~B}$ & 0.23 \\
$\mathrm{CuSO}_{4}$ & 0.03 \\
$\mathrm{Na}_{2} \mathrm{MoO}_{4}$ & 0.01 \\
\hline
\end{tabular}

The environmental conditions in the greenhouse were monitored during the growing cycle (Figure A1 in the Appendix A). Relative air humidity was maintained between 70 and $80 \%$ (77\% on average during the entire growing cycle). Temperature and light intensity were more variable, as they were influenced by external conditions, although a minimum threshold of $12{ }^{\circ} \mathrm{C}$ at night and $16{ }^{\circ} \mathrm{C}$ during the day were set for starting automatic heating. The daily mean temperature over the period was $17.2{ }^{\circ} \mathrm{C}$ and the mean light intensity was $137 \mathrm{klx} \mathrm{h}^{-1}$. The light intensity was measured with a digital photometer (LI-250A, LI-COR Inc., Lincoln, NE, USA) equipped with a photometric sensor.

\subsubsection{Spring Trial}

The spring elemental experiment was arranged as a randomized complete block (RCB) with 4 replicates and 6 treatments, as follows: T1, continuous fertilization; T2, fertilization stopped during the last 2 days; T3, fertilization stopped during the last 4 days; T4, fertilization stopped during the last 6 days; T5, fertilization stopped during the last 8 days; T6, fertilization stopped during the last 10 days. Similar to the autumn trial, the total number of plots was 24 and the experiment was repeated 
6 times in order to investigate responses from 25- to 30-day growing cycles, using lettuce seedlings (cv. Tourbillon, Batavia type).

The concentrated nutrient solutions (A and B) were stored as in the autumn trial and their composition is indicated in Table 1 . The diluted nutrient solution had the following physicochemical characteristics: nitrogen concentration $\left(\mathrm{NO}_{3}{ }^{-}+\mathrm{NH}_{4}{ }^{+}\right) 13.8 \mathrm{mmol} \mathrm{L}{ }^{-1} ; \mathrm{pH}$ 6.6; EC $1.92 \mathrm{mS} \mathrm{cm}{ }^{-1}$. The fertilization program consisted of 23 irrigations per day, each of them lasting $2 \mathrm{~min}$, at a flow rate of $0.4 \mathrm{~L} \mathrm{~min}{ }^{-1}$. Each plant received $0.32 \mathrm{~L}$ of water per day. Excess nutrient solution collected from the greenhouse benches was reused after adjustment and sterilization as in the previous trial.

Relative humidity was maintained almost constant, with a mean of $73 \%$ during the growing cycle. Light intensity, and to a greater degree air temperature, were not as steady, as they were influenced by external conditions, with no artificial heating being used. The daily mean temperature over the period was $14.4{ }^{\circ} \mathrm{C}$ and the mean light intensity was $188 \mathrm{klx} \mathrm{h}^{-1}$, as per instrumental detection (Figure A2 in the Appendix A).

\subsection{Plant Sampling and Yield Measurements}

In the autumn trial, the harvest of lettuce plants took place at 25, 26, 27, 28, 29, and 30 DAT, from 27th October to 1st November 2014. Two plants from each plot were sampled randomly and the fresh biomass yield (FBY) was immediately determined by weighing it. Dry biomass yield (DBY) was then calculated by multiplying FBY by dry matter content (DMC), as obtained after drying the fresh biomass in a forced oven at $65^{\circ} \mathrm{C}$ until constant weight.

Using the same procedure in the spring trial, two plants of lettuce from each plot were sampled randomly at 25, 26, 27, 28, 29, and 30 DAT, from 1st April to 6th April 2014 in order to determine FBY, DMC, and DBY.

\subsection{Nitrate Concentration in the Plant}

The concentration of $\mathrm{NO}_{3}{ }^{-}$in the lettuce was determined on fresh and dry matter basis by ion chromatograph (Dionex DX-120) provided by the pre-guard column AG9HC (4 mm $\times 50 \mathrm{~mm})$ and the column AS9HC $(4 \mathrm{~mm} \times 250 \mathrm{~mm})$. The analytical parameters were sodium carbonate/sodium

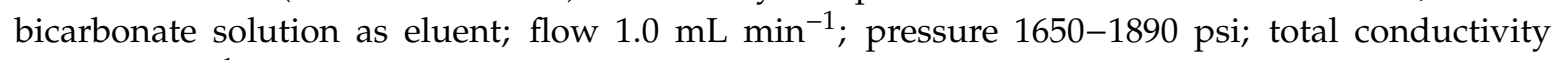
24-28 $\mu \mathrm{S} \mathrm{cm}^{-1}$; nitrate retention time 6.95-7.28 $\min$ [24].

Dried lettuce leaf samples were ground at $2 \mathrm{~mm}$. Extraction was performed according to the method of Santamaria et al. [24], which is based on cold extraction of nitrates using a solution of sodium carbonate $0.5 \mathrm{M}$ and sodium bicarbonate $0.5 \mathrm{M}$, the same solution used as eluent. Then, $1 \mathrm{~g}$ of dried lettuce leaf was added to $50 \mathrm{~mL}$ of extraction solution and shaken for $20 \mathrm{~min}$ at $150 \mathrm{rpm}$. The extract was filtered with Whatman paper No. 1 and then with a $0.45-\mu \mathrm{m}$ syringe filter combined with an On-Guard IIP (Dionex) cartridge. The filtered extract was injected into the ion chromatograph after appropriate dilution.

\subsection{Statistical Analysis}

Data on FBY, DBY, DMC, and $\mathrm{NO}_{3}{ }^{-}$concentration for each trial and harvest date were subjected to analysis of variance (ANOVA) using the statistical software SAS version 9.2 (SAS Institute Inc., Cary, NC, USA, 2009). When normal distribution was not confirmed by the Shapiro-Wilk test, data were log-transformed before analysis. Tukey's test was used to test for significant differences in variables among treatments with a $p$-value $\leq 0.05$ as the threshold for statistical significance. 


\section{Results}

\subsection{Biomass Yield and Dry Matter Content in Leaves}

\subsubsection{Autumn Trial}

Results on fresh biomass yield (FBY) showed no differences among fertilization treatments across all growing cycle durations (Table 2). Fresh biomass yield of T5 treatment was not available due to fungal diseases in two out of four replicates. In any case, not even a tendency to reduce FBY passing from T1 to T5 was observed. A similar pattern was found for dry biomass yield (DBY), which led to no statistical difference among treatments (Table 3).

Table 2. Autumn trial: fresh biomass yield of lettuce per type of fertilization treatment.

\begin{tabular}{|c|c|c|c|c|c|c|}
\hline \multirow{2}{*}{ Treatment ${ }^{1}$} & \multicolumn{6}{|c|}{ Fresh Biomass Yield (g plant ${ }^{-1}$ ) } \\
\hline & 25 DAT $^{2}$ & 26 DAT & 27 DAT & 28 DAT & 29 DAT & 30 DAT \\
\hline $\mathrm{T} 1$ & 74.7 & 95.7 & 93.1 & 111.4 & 107.5 & 121.8 \\
\hline $\mathrm{T} 2$ & 70.4 & 94.0 & 87.6 & 103.9 & 98.8 & 117.5 \\
\hline $\mathrm{T} 3$ & 77.1 & 92.6 & 90.9 & 114.4 & 110.7 & 111.5 \\
\hline $\mathrm{T} 4$ & 83.7 & 79.3 & 93.6 & 95.6 & 80.3 & 112.9 \\
\hline $\mathrm{T} 5$ & 79.1 & 77.2 & 85.0 & 108.0 & 104.2 & n. a. ${ }^{4}$ \\
\hline T6 & 73.4 & 81.7 & 96.0 & 106.7 & 79.1 & 113.8 \\
\hline Mean & 76.4 & 86.7 & 91.1 & 106.7 & 106.7 & 115.5 \\
\hline Significance $^{3}$ & n. s. & n. s. & n. s. & n. s. & n. s. & n. s. \\
\hline
\end{tabular}

Notes: ${ }^{1}$ T1: fertilization never reduced; T2: fertilization stopped on the last 2 days; T3: fertilization stopped on the last 4 days; T4: fertilization stopped on the last 6 days; T5: fertilization stopped on the last 8 days; T6: fertilization stopped on the last 10 days. ${ }^{2}$ DAT: days after transplanting. ${ }^{3}$ Within columns, means followed by different letters are significantly different according to the Tukey's test. n.s.: not significant. ${ }^{4}$ n.a.: not available.

Table 3. Autumn trial: dry biomass yield of lettuce per type of fertilization treatment.

\begin{tabular}{ccccccc}
\hline \multirow{2}{*}{ Treatment $^{\mathbf{1}}$} & \multicolumn{7}{c}{ Dry Biomass Yield (g plant ${ }^{\mathbf{- 1}}$ ) } \\
\cline { 2 - 7 } & 25 DAT $^{\mathbf{2}}$ & 26 DAT & 27 DAT & 28 DAT & 29 DAT & 30 DAT \\
\hline T1 & 2.8 & 4.0 & 3.7 & 3.8 & 4.6 & 4.2 \\
T2 & 2.7 & 3.9 & 3.5 & 3.5 & 4.6 & 4.0 \\
T3 & 3.0 & 3.9 & 4.0 & 3.3 & 4.3 & 3.9 \\
T4 & 3.1 & 3.1 & 4.0 & 4.2 & 3.3 & 5.4 \\
T5 & 3.1 & 3.2 & 3.3 & 4.3 & 4.1 & n.a. \\
T6 & 3.2 & 3.2 & 3.9 & 4.1 & 4.0 & 5.1 \\
\hline Mean & 3.0 & 3.6 & 3.7 & 3.9 & 3.8 & 4.5 \\
Significance $^{3}$ & n. s. & n. s. & n. s. & n. s. & n. s. & n. s. \\
\hline
\end{tabular}

Notes: ${ }^{1}$ T1: fertilization never reduced; T2: fertilization stopped on the last 2 days; T3: fertilization stopped on the last 4 days; T4: fertilization stopped on the last 6 days; T5: fertilization stopped on the last 8 days; T6: fertilization stopped on the last 10 days. ${ }^{2}$ DAT: days after transplanting. ${ }^{3}$ Within columns, means followed by different letters are significantly different according to the Tukey's test. n.s.: not significant. ${ }^{4}$ n.a.: not available.

As regards dry matter content (DMC) (Table 4), mean values of single treatments ranged from 3.7 to $4.4 \%$ across the six growing cycle durations. Here also, no clear pattern of DMC accumulation in relation to the length of the growing cycle was found. Only in the 28-DAT and 30-DAT cycles were some statistical differences found among treatments and a slight increase in DMC from T4 to T6 was recorded. 
Table 4. Autumn trial: dry matter content in lettuce per type of fertilization treatment.

\begin{tabular}{ccccccc}
\hline \multirow{2}{*}{ Treatments $^{\mathbf{1}}$} & \multicolumn{7}{c}{ Dry Matter Percentage of Lettuce (\%) } \\
\cline { 2 - 7 } & 25 DAT $^{2}$ & 26 DAT & 27 DAT & 28 DAT & 29 DAT & 30 DAT \\
\hline T1 & 3.7 & 3.8 & 4.0 & $3.4 \mathrm{bc}$ & 4.3 & $3.5 \mathrm{~b}$ \\
T2 & 3.8 & 4.2 & 4.1 & $3.4 \mathrm{bc}$ & 4.1 & $3.4 \mathrm{~b}$ \\
T3 & 3.9 & 3.9 & 4.3 & $3.3 \mathrm{c}$ & 3.9 & $3.5 \mathrm{~b}$ \\
T4 & 3.7 & 3.9 & 4.2 & $4.1 \mathrm{a}$ & 4.2 & $4.7 \mathrm{a}$ \\
T5 & 4.0 & 4.1 & 3.9 & $4.0 \mathrm{a}$ & 3.9 & n. a. ${ }^{\circ}$ \\
T6 & 4.1 & 4.0 & 4.1 & $3.8 \mathrm{ab}$ & 5.8 & 4.5 a \\
\hline Mean & 3.9 & 4.0 & 4.1 & 3.7 & 4.4 & 3.9 \\
Significance $^{3}$ & n. s. & n. s. & n. s. & $* * *$ & n. s. & $* * *$ \\
\hline
\end{tabular}

Notes: ${ }^{1} \mathrm{~T} 1$ : fertilization never reduced; T2: fertilization stopped on the last 2 days; T3: fertilization stopped on the last 4 days; T4: fertilization stopped on the last 6 days; T5: fertilization stopped on the last 8 days; T6: fertilization stopped on the last 10 days. ${ }^{2}$ DAT: days after transplanting. ${ }^{3}$ Within columns, means followed by different letters are significantly different according to the Tukey's test. ${ }^{* * *}$ refers to significance levels of $p \leq 0.001$, respectively. n.s.: not significant. ${ }^{4}$ n.a.: not available.

\subsubsection{Spring Trial}

Results on the relationships between fertilization treatments and FBY across all the six growing cycle durations (Table 5) showed that, on average, FBY increased by $52 \%$ passing from 25 to 30 DAT. All the growing cycle durations ( 25 to $30 \mathrm{DAT}$ ) showed statistical differences among $\mathrm{T} 1 \div \mathrm{T} 6$ with varying extents. Contrary to the autumn trial, FBY always decreased passing from T1 to T6. This reduction in FBY was statistically evident especially for T3, when fertilization was stopped during the last 4 days of the growing cycle (or T4 for the 26-DAT cycle, when fertilization was stopped for 6 days).

Table 5. Spring trial: fresh biomass yield of lettuce per type of fertilization treatment.

\begin{tabular}{ccccccc}
\hline \multirow{2}{*}{ Treatments $^{1}$} & \multicolumn{7}{c}{ Fresh Biomass Yield (g plant $^{-\mathbf{1}}$ ) } \\
\cline { 2 - 7 } & 25 DAT & 26 DAT & 27 DAT & 28 DAT & 29 DAT & 30 DAT \\
\hline T1 & $109.5 \mathrm{a}$ & $116.8 \mathrm{a}$ & $134.2 \mathrm{a}$ & $149.3 \mathrm{a}$ & $168.9 \mathrm{a}$ & $160.6 \mathrm{a}$ \\
$\mathrm{T} 2$ & $101.9 \mathrm{ab}$ & $112.2 \mathrm{a}$ & $126.8 \mathrm{ab}$ & $135.2 \mathrm{ab}$ & $154.4 \mathrm{ab}$ & $157.3 \mathrm{ab}$ \\
T3 & $92.7 \mathrm{bc}$ & $102.1 \mathrm{a}$ & $116.3 \mathrm{~b}$ & $122.4 \mathrm{bc}$ & $146.4 \mathrm{bc}$ & $133.2 \mathrm{bc}$ \\
T4 & $88.3 \mathrm{c}$ & $79.8 \mathrm{~b}$ & $97.1 \mathrm{c}$ & $107.0 \mathrm{~cd}$ & $130.7 \mathrm{c}$ & $128.1 \mathrm{c}$ \\
T5 & $70.2 \mathrm{~d}$ & $81.1 \mathrm{~b}$ & $93.3 \mathrm{c}$ & $100.9 \mathrm{~d}$ & $103.7 \mathrm{~d}$ & $114.5 \mathrm{c}$ \\
T6 & $66.2 \mathrm{~d}$ & $71.0 \mathrm{~b}$ & $69.0 \mathrm{~d}$ & $90.9 \mathrm{~d}$ & $102.1 \mathrm{~d}$ & $112.3 \mathrm{c}$ \\
\hline Mean & 88.1 & 93.8 & 106.1 & 117.6 & 134.3 & 134.3 \\
Significance $^{3}$ & $* * *$ & $* * *$ & $* * *$ & $* * *$ & $* * *$ & $*$ \\
\hline
\end{tabular}

Notes: ${ }^{1} \mathrm{~T} 1$ : fertilization never reduced; T2: fertilization stopped on the last 2 days; T3: fertilization stopped on the last 4 days; T4: fertilization stopped on the last 6 days; T5: fertilization stopped on the last 8 days; T6: fertilization stopped on the last 10 days. ${ }^{2}$ DAT: days after transplanting. ${ }^{3}$ Within columns, means followed by different letters are significantly different according to the Tukey's test. ${ }^{* * *}$ refers to significance levels of $p \leq 0.001$, respectively. n.s: not significant.

The same pattern was shown in the DBY (Table 6), even though with a fewer number of differences, and at weaker probability levels. In detail, DBY increased from 5.0 to $6.8 \mathrm{~g} \mathrm{plant}^{-1}$, passing from 25- to 30-DAT growing cycle duration. 
Table 6. Spring trial: dry biomass yield of lettuce per type of fertilization treatment.

\begin{tabular}{ccccccc}
\hline \multirow{2}{*}{ Treatments $^{\mathbf{1}}$} & \multicolumn{7}{c}{ Dry Biomass Yield (g plant } & -1) \\
\cline { 2 - 7 } & 25 DAT $^{\mathbf{2}}$ & 26 DAT & 27 DAT & 28 DAT & 29 DAT & 30 DAT \\
\hline T1 & 5.1 & 5.8 & $6.2 \mathrm{a}$ & 6.8 & $7.2 \mathrm{a}$ & 7.2 \\
T2 & 5.0 & 5.6 & $5.6 \mathrm{ab}$ & 6.1 & $6.7 \mathrm{ab}$ & 6.8 \\
T3 & 4.9 & 5.8 & $5.8 \mathrm{a}$ & 6.2 & $6.8 \mathrm{ab}$ & 6.9 \\
T4 & 5.4 & 5.2 & $5.7 \mathrm{ab}$ & 6.2 & $7.1 \mathrm{a}$ & 6.9 \\
T5 & 4.8 & 5.7 & $6.2 \mathrm{a}$ & 6.2 & $6.4 \mathrm{ab}$ & 6.7 \\
T6 & 4.8 & 5.1 & $4.8 \mathrm{~b}$ & 6.0 & $6.2 \mathrm{~b}$ & 6.5 \\
\hline Mean & 5.0 & 5.5 & 5.7 & 6.2 & 6.7 & 6.8 \\
Significance $^{3}$ & n. s. & n. s. & $* *$ & n. s. & $*$ & n.s. \\
\hline
\end{tabular}

Notes: ${ }^{1} \mathrm{~T} 1$ : fertilization never reduced; T2: fertilization stopped on the last 2 days; T3: fertilization stopped on the last 4 days; T4: fertilization stopped on the last 6 days; T5: fertilization stopped on the last 8 days; T6: fertilization stopped on the last 10 days. ${ }^{2}$ DAT: days after transplanting. ${ }^{3}$ Within columns, means followed by different letters are significantly different according to the Tukey's test. ${ }^{*}$ and ${ }^{* *}$ refers to significance levels of $p \leq 0.05$ and $p \leq 0.01$. n.s: not significant.

Lettuce DMC was affected by fertilization treatments (Table 7) in all cycle durations. The DMC increased almost steadily, from T1 to T6.

Table 7. Spring trial: dry matter content in lettuce per type of fertilization treatment.

\begin{tabular}{ccccccc}
\hline \multirow{2}{*}{ Treatment $^{\mathbf{1}}$} & \multicolumn{7}{c}{ Dry Matter Percentage of Lettuce (\%) } \\
\cline { 2 - 7 } & 25 DAT $^{2}$ & 26 DAT & 27 DAT & 28 DAT & 29 DAT & 30 DAT \\
\hline T1 & $4.7 \mathrm{e}$ & $5.0 \mathrm{~d}$ & $4.6 \mathrm{c}$ & $4.5 \mathrm{~d}$ & $4.2 \mathrm{~d}$ & $4.5 \mathrm{c}$ \\
$\mathrm{T} 2$ & $4.9 \mathrm{e}$ & $4.9 \mathrm{~d}$ & $4.4 \mathrm{c}$ & $4.5 \mathrm{~d}$ & $4.4 \mathrm{~cd}$ & $4.4 \mathrm{c}$ \\
$\mathrm{T} 3$ & $5.3 \mathrm{~d}$ & $5.7 \mathrm{c}$ & $5.0 \mathrm{c}$ & $5.1 \mathrm{c}$ & $4.7 \mathrm{c}$ & $5.2 \mathrm{c}$ \\
T4 & $6.1 \mathrm{c}$ & $6.6 \mathrm{~b}$ & $5.8 \mathrm{~b}$ & $5.9 \mathrm{~b}$ & $5.4 \mathrm{~b}$ & $5.5 \mathrm{ab}$ \\
T5 & $6.9 \mathrm{~b}$ & $7.0 \mathrm{a}$ & $6.6 \mathrm{a}$ & $6.1 \mathrm{ab}$ & $6.1 \mathrm{a}$ & $5.8 \mathrm{a}$ \\
T6 & $7.2 \mathrm{a}$ & $7.2 \mathrm{a}$ & $6.9 \mathrm{a}$ & $6.6 \mathrm{a}$ & $6.1 \mathrm{a}$ & $5.9 \mathrm{a}$ \\
\hline Mean & 5.8 & 6.1 & 5.6 & 5.46 & 5.2 & 5.2 \\
Significance $^{3}$ & $* * *$ & $* * *$ & $* * *$ & $* * *$ & $* * *$ & $* * *$ \\
\hline
\end{tabular}

Notes: ${ }^{1} \mathrm{~T} 1$ : fertilization never reduced; T2: fertilization stopped on the last 2 days; T3: fertilization stopped on the last 4 days; T4: fertilization stopped on the last 6 days; T5: fertilization stopped on the last 8 days; T6: fertilization stopped on the last 10 days. ${ }^{2}$ DAT: days after transplanting. ${ }^{3}$ Within columns, means followed by different letters are significantly different according to the Tukey's test. ${ }^{* * *}$ refers to significance levels of $p \leq 0.001$.

\subsection{Effect of Treatment on Nitrate Concentration}

\subsubsection{Autumn Trial}

Differences among fertilization treatments were observed in two out of six growing cycle durations (25 and $28 \mathrm{DAT})$. In both of them, nitrates $\left(\mathrm{NO}_{3}{ }^{-}\right)$concentration on fresh matter basis showed an increasing pattern as one passed from $\mathrm{T} 1$ to $\mathrm{T} 6$ (Table 8). On average, values of $\mathrm{NO}_{3}{ }^{-}$concentration on fresh matter basis varied widely between growing cycles and tended to be lower in the shortest than in the longest ones (from 2244 to $3264 ;+45 \%$ ). 
Table 8. Autumn trial: nitrate concentration in lettuce on fresh matter basis.

\begin{tabular}{|c|c|c|c|c|c|c|}
\hline \multirow{2}{*}{ Treatments ${ }^{1}$} & \multicolumn{6}{|c|}{ Nitrates Concentration (mg NO${ }_{3}^{-} \mathbf{k g}^{-1}$ on $\mathrm{f} . \mathrm{m}$. basis) } \\
\hline & 25 DAT $^{2}$ & 26 DAT & 27 DAT & 28 DAT & 29 DAT & 30 DAT \\
\hline $\mathrm{T} 1$ & $2017 \mathrm{ab}$ & 2662 & 2693 & $2686 \mathrm{ab}$ & 3391 & 2832 \\
\hline $\mathrm{T} 2$ & $1775 \mathrm{~b}$ & 2876 & 2741 & $2618 \mathrm{ab}$ & 3039 & 2781 \\
\hline T3 & $2360 \mathrm{ab}$ & 2472 & 2774 & $2463 \mathrm{~b}$ & 2997 & 2705 \\
\hline $\mathrm{T} 4$ & $2028 \mathrm{ab}$ & 2433 & 2754 & 3018 a & 3118 & 3415 \\
\hline T5 & $2615 \mathrm{a}$ & 2462 & 2405 & 2930 a & 2758 & n. a. 4 \\
\hline T6 & $2671 \mathrm{a}$ & 2383 & 2531 & $2890 \mathrm{ab}$ & 4282 & 3228 \\
\hline Mean & 2244 & 2548 & 2650 & 2768 & 3264 & 2992 \\
\hline Significance $^{3}$ & $* *$ & n. s. & n. s. & $* *$ & n. s. & n. s. \\
\hline
\end{tabular}

Notes ${ }^{1}$ T1: fertilization never reduced; T2: fertilization stopped on the last 2 days; T3: fertilization stopped on the last 4 days; T4: fertilization stopped on the last 6 days; T5: fertilization stopped on the last 8 days; T6: fertilization stopped on the last 10 days. ${ }^{2}$ DAT: days after transplanting. ${ }^{3}$ Within columns, means followed by different letters are significantly different according to the Tukey's test. ${ }^{* *}$ refers to significance levels of $p \leq 0.01$. n.s: not significant.

${ }^{4}$ n.a.: not available.

The $\mathrm{NO}_{3}{ }^{-}$concentration on dry matter basis was affected by treatments only in the first (25-DAT) and the last (30-DAT) growing cycle duration (Table 9), but with contrary effects: in the 25-DAT cycle it increased from T1 to T5, while in the 30-DAT cycle it decreased from T1 to T5 (from 81,901 mg $\mathrm{NO}_{3}{ }^{-} \mathrm{kg}^{-1}$ in $\mathrm{T} 1$ down to $71,756 \mathrm{mg} \mathrm{NO}_{3}{ }^{-} \mathrm{kg}^{-1}$ in $\mathrm{T} 6(-12 \%)$ ). Similarly to $\mathrm{NO}_{3}{ }^{-}$concentration on a fresh matter basis, when evaluated over the different growing cycles, the treatment means for $\mathrm{NO}_{3}{ }^{-}$ concentration on dry matter basis tended to increase from 25- $\left(58,014 \mathrm{mg} \mathrm{NO}_{3}{ }^{-} \mathrm{kg}^{-1}\right)$ to 30-DAT cycles (76,985 $\left.\mathrm{mg} \mathrm{NO}_{3}^{-} \mathrm{kg}^{-1}\right)$.

Table 9. Autumn trial: nitrate concentration in lettuce on dry matter basis.

\begin{tabular}{|c|c|c|c|c|c|c|}
\hline \multirow{2}{*}{ Treatments ${ }^{1}$} & \multicolumn{6}{|c|}{ Nitrates Concentration (mg $\mathrm{NO}_{3}{ }^{-} \mathrm{kg}^{-1}$ on $\mathrm{d}$. m. basis) } \\
\hline & 25 DAT $^{2}$ & 26 DAT & 27 DAT & 28 DAT & 29 DAT & 30 DAT \\
\hline $\mathrm{T} 1$ & $53,885 a b$ & 70,532 & 67,112 & 78,990 & 79,251 & 81,901 a \\
\hline $\mathrm{T} 2$ & $46,491 \mathrm{~b}$ & 68,947 & 67,748 & 77,781 & 74,531 & 81,717 a \\
\hline T3 & 60,325 a & 64,135 & 65,725 & 76,239 & 77,156 & $77,589 \mathrm{ab}$ \\
\hline $\mathrm{T} 4$ & $55,089 \mathrm{ab}$ & 62,641 & 65,010 & 73,110 & 73,842 & $71,962 \mathrm{~b}$ \\
\hline T5 & $65,954 \mathrm{a}$ & 59,674 & 62,535 & 74,266 & 70,041 & n. a. ${ }^{4}$ \\
\hline T6 & $66,339 a$ & 60,057 & 62,800 & 75,681 & 73,797 & $71,756 \mathrm{~b}$ \\
\hline Mean & 58,014 & 64,331 & 65,155 & 76,011 & 74,769 & 76,985 \\
\hline Significance $^{3}$ & * & n. s. & n. s. & n. s. & n. s. & $* * *$ \\
\hline
\end{tabular}

Notes ${ }^{1}$ T1: fertilization never reduced; T2: fertilization stopped on the last 2 days; T3: fertilization stopped on the last 4 days; T4: fertilization stopped on the last 6 days; T5: fertilization stopped on the last 8 days; T6: fertilization stopped on the last 10 days. ${ }^{2}$ DAT: days after transplanting. ${ }^{3}$ Within columns, means followed by different letters are significantly different according to the Tukey's test. ${ }^{*}, * * * *$ refer to significance levels of $p \leq 0.05$, and $p \leq 0.001$, respectively. n.s: not significant. ${ }^{4}$ n.a.: not available.

\subsubsection{Spring Trial}

Similarly to results of the autumn trial, $\mathrm{NO}_{3}{ }^{-}$concentration on fresh matter basis increased with the longer growing cycle duration (Table 10). However, values in the spring trial were much lower than those in the autumn trial ( -40 to $-60 \%)$ over the six growing cycle durations. Overall, fertilization treatments had always an effect on $\mathrm{NO}_{3}{ }^{-}$concentration on fresh matter basis. In detail, $\mathrm{NO}_{3}{ }^{-}$concentration on fresh matter basis decreased from $\mathrm{T} 1$ to $\mathrm{T} 6$ in all growing cycle durations. With T1, values went from a minimum of 2539 (25 DAT) to a maximum of $4034 \mathrm{mg} \mathrm{NO}_{3}{ }^{-} \mathrm{kg}^{-1}$ (29 DAT), whereas with $\mathrm{T} 6$ the $\mathrm{NO}_{3}{ }^{-}$concentration on fresh matter basis was reduced by 90 to $95 \%$, compared with T1. 
Table 10. Spring trial: nitrate concentration in lettuce on fresh matter basis.

\begin{tabular}{|c|c|c|c|c|c|c|}
\hline \multirow{2}{*}{ Treatment $^{1}$} & \multicolumn{6}{|c|}{ Nitrate Concentration (mg $\mathrm{NO}_{3}{ }^{-} \mathrm{kg}^{-1}$ on $\mathrm{f} . \mathrm{m}$. basis) } \\
\hline & 25 DAT $^{2}$ & 26 DAT & 27 DAT & 28 DAT & 29 DAT & 30 DAT \\
\hline $\mathrm{T} 1$ & 2539 a & 2349 a & $3212 \mathrm{a}$ & 3660 a & $4034 \mathrm{a}$ & 3932 a \\
\hline $\mathrm{T} 2$ & $1683 \mathrm{~b}$ & $1511 \mathrm{~b}$ & $2332 \mathrm{~b}$ & $2711 \mathrm{~b}$ & $3267 \mathrm{~b}$ & $2592 b$ \\
\hline T3 & $1173 \mathrm{bc}$ & $759 c$ & $1384 \mathrm{c}$ & 1504 c & $2074 \mathrm{c}$ & 1409 c \\
\hline $\mathrm{T} 4$ & $388 \mathrm{~cd}$ & $612 c$ & $446 \mathrm{~d}$ & $859 \mathrm{~d}$ & $1191 \mathrm{~d}$ & $784 \mathrm{~cd}$ \\
\hline $\mathrm{T} 5$ & $214 \mathrm{~d}$ & $395 \mathrm{~cd}$ & $290 d$ & $667 \mathrm{de}$ & $556 \mathrm{e}$ & $452 \mathrm{~d}$ \\
\hline T6 & $166 \mathrm{~d}$ & $206 d$ & $151 \mathrm{~d}$ & $210 \mathrm{e}$ & 419 e & $401 \mathrm{~d}$ \\
\hline Mean & 1027 & 972 & 1302 & 1602 & 1923 & 1595 \\
\hline Significance $^{3}$ & $* * *$ & $* * *$ & $* * *$ & $* * *$ & $* * *$ & $* * *$ \\
\hline
\end{tabular}

Notes: ${ }^{1}$ T1: fertilization never reduced; T2: fertilization stopped on the last 2 days; T3: fertilization stopped on the last 4 days; T4: fertilization stopped on the last 6 days; T5: fertilization stopped on the last 8 days; T6: fertilization stopped on the last 10 days. ${ }^{2}$ DAT: days after transplanting. ${ }^{3}$ Within columns, means followed by different letters are significantly different according to the Tukey's test. ${ }^{* * *}$ refers to significance levels of $p \leq 0.001$.

$\mathrm{NO}_{3}{ }^{-}$concentration on dry matter basis revealed a decreasing pattern very similar to that on fresh matter basis (Table 11 ). Up to treatment $\mathrm{T} 3$, the decrease was very sharp (-62\% on average), then the decline became less rapid, reaching $-94 \%$ with treatment $\mathrm{T} 6$.

Table 11. Spring trial: nitrate concentration in lettuce on dry matter basis.

\begin{tabular}{|c|c|c|c|c|c|c|}
\hline \multirow{2}{*}{ Treatment ${ }^{1}$} & \multicolumn{6}{|c|}{ Nitrate Concentration (mg $\mathrm{NO}_{3}{ }^{-} \mathrm{kg}^{-1}$ on $\mathrm{d} . \mathrm{m}$. basis) } \\
\hline & $25 \mathrm{DAT}^{2}$ & 26 DAT & 27 DAT & 28 DAT & 29 DAT & 30 DAT \\
\hline $\mathrm{T} 1$ & 59,899 a & 47,203 a & 69,614 a & 81,427 a & $95,445 \mathrm{a}$ & 87,369 a \\
\hline $\mathrm{T} 2$ & $38,468 \mathrm{~b}$ & $30,610 \mathrm{~b}$ & $53,139 \mathrm{~b}$ & $62,444 \mathrm{~b}$ & $75,452 \mathrm{~b}$ & $60,100 \mathrm{~b}$ \\
\hline T3 & $25,329 \mathrm{bc}$ & $13,535 \mathrm{c}$ & $28,146 \mathrm{c}$ & $29,169 \mathrm{c}$ & $45,132 \mathrm{c}$ & $27,460 \mathrm{c}$ \\
\hline $\mathrm{T} 4$ & 7157 cd & $9404 \mathrm{~cd}$ & $7689 \mathrm{~d}$ & $15,688 \mathrm{~d}$ & $22,057 \mathrm{~d}$ & $14,616 \mathrm{c}$ \\
\hline $\mathrm{T} 5$ & $3506 \mathrm{~d}$ & $5683 \mathrm{~cd}$ & $4390 \mathrm{~d}$ & $11,425 \mathrm{~d}$ & 9125 de & $7759 c$ \\
\hline T6 & $2734 \mathrm{~d}$ & $2853 \mathrm{~d}$ & $2201 \mathrm{~d}$ & $3782 \mathrm{~d}$ & $7051 \mathrm{e}$ & 7012 c \\
\hline Mean & 22,849 & 18,215 & 27,530 & 33,989 & 42,377 & 34,053 \\
\hline Significance $^{3}$ & $* * *$ & $* * *$ & $* * *$ & $* * *$ & $* * *$ & $* * *$ \\
\hline
\end{tabular}

Notes: ${ }^{1}$ T1: fertilization never reduced; T2: fertilization stopped on the last 2 days; T3: fertilization stopped on the last 4 days; T4: fertilization stopped on the last 6 days; T5: fertilization stopped on the last 8 days; T6: fertilization stopped on the last 10 days. ${ }^{2}$ DAT: days after transplanting. ${ }^{3}$ Within columns, means followed by different letters are significantly different according to the Tukey's test. ${ }^{* * *}$ refers to significance levels of $p \leq 0.001$.

\section{Discussion}

Overall, we can report that in the present study, lettuce FBY and DBY were higher in the spring trial than in the autumn trial, corroborating previous studies $[14,25]$ that showed that external seasonal climatic conditions (i.e., light intensity, photoperiod length, and air temperatures) may affect greenhouse growing conditions.

More in detail, findings on biomass yield (i.e., FBY and DBY) obtained with the autumn trial in the present study were not in agreement with the experimental hypothesis. Stopping the fertilization in treatments from T2 to T6 was indeed expected to decrease both FBY and DBY [26]. Conversely, our results did not show a specific pattern, neither for FBY nor for DBY. In detail, the fertilization suspension during the last ten days of the cropping cycle was irrelevant for affecting lettuce yields in the autumn conditions. A possible explanation to these results lies in the fluctuating light-intensity pattern during the autumn trial, despite the regulating system inside the greenhouse. Light intensity indeed peaked several times during the growing season and was very low for the rest of time. Thus, such unfavorable growing conditions had detrimental effects on FBY, as previously shown in several studies. For instance, Burns et al. [27] found that reducing the light intensity by $50 \%$ may lead to a halving of FBY in a 28-day trial. Delaide et al. [28] confirmed these results. Also, variations observed 
in DMC and, consequently, on DBY seem to be directly correlated with scarce light intensity in the autumn trial. Specifically, the lowest dry matter content was found in the 28-DAT growing cycle, right after a severe drop in light intensity for 3 consecutive days immediately preceding the harvest. Therefore, based on our results, the best length of the autumn growing cycle for obtaining maximum fresh weight is $30 \mathrm{DAT}$, which led to a $51 \%$ increase in either FBY or DBY with a 5-day elongation of the cycle.

Similarly, during the spring trial, FBY increased by $52 \%$ as one passed from the 25 -DAT to the 30-DAT growing cycle. This increase in FBY clearly indicates that the 30-DAT cycle could be suggested as a means to maximize fresh yield in lettuce also for spring growing cycles. Our results, additionally, suggest that stopping the fertilization from 6 to 10 days before the harvest in the spring cycle is not indicated for the purpose of maximizing FBY. Fresh biomass yield was indeed, on average, $40 \%$ lower for plants under T6 than under T1. Also, the increase in DBY was of about 37\% passing from the 25to 30-DAT growing cycle, while the interruption of fertilization in the last days of the cycle led to an average DBY decrease of about $13 \%$ passing from $\mathrm{T} 1$ to $\mathrm{T} 6$. This low reduction in DBY compared with the high one in FBY is probably related to different values of DMC of plants in different treatments. In detail, DMC increased as nitrogen fertilization decreased, passing from $4.6 \%$ on average under $\mathrm{T} 1$ to $6.7 \%$ under T6. These results could be explained by the osmotic effect caused by nitrate accumulation as reported by Tei et al. [29] and corroborate earlier studies indicating that the leaf nitrate content is correlated positively with plant fresh weight, but negatively with dry matter content $[21,30]$. The lettuce DMC during the spring trial was not only affected by $\mathrm{N}$ fertilization but was directly correlated with light intensity. On average, during the spring cycle the dry matter accumulation in lettuce was about $40 \%$ higher than that observed during the autumn cycle, confirming previous results from a double-season experiment of Lopes et al. [31], who found that lettuce during the spring trial accumulated around $30 \%$ more DM than during the autumn trial.

As regards $\mathrm{NO}_{3}{ }^{-}$concentration, the spring trial showed much lower values that the autumn trial, probably due to more favorable light conditions, photoperiod length and air temperatures, as previously reported by Guadagnin et al. [25] and Fallovo et al. [14]. In any case, mean $\mathrm{NO}_{3}{ }^{-}$concentration in the leaves for all cycles and fertilization treatments were always below $5000 \mathrm{mg} \mathrm{NO}_{3}{ }^{-} \mathrm{kg}^{-1}$, the value set by the European Union as the legislative threshold for winter lettuce. Tamme et al. [32], in a previous greenhouse study on lettuce under similar conditions, reported that $\mathrm{NO}_{3}{ }^{-}$concentration in leaves was lower in the summer cycle (on average $1952 \mathrm{mg} \mathrm{NO}_{3}{ }^{-}-\mathrm{kg}^{-1}$ ) than in the winter cycle $\left(3024 \mathrm{mg} \mathrm{kg}^{-1}\right)$, though it never exceeded the EU threshold.

As reported by $\mathrm{Kmecl}$ et al. [5], the $\mathrm{NO}_{3}{ }^{-}$concentration in vegetables is highly correlated with a number of different factors, such as the substrate characteristics and the rate of fertilization, which could affect the intensity of metabolic processes in the different organs of plants and in leaves. Also when using other growing systems, such as the aeroponic system, the concentration of nitrogen compounds $\left(\mathrm{NO}_{3}-\mathrm{N}, \mathrm{NH}_{4}-\mathrm{N}\right.$ and total $\mathrm{N}$ ) in lettuce (cv. capitata) was shown to be highly affected by the $\mathrm{NO}_{3}{ }^{-}$concentration in the nutrient solution and by the specific growing conditions [33]. Marsic et al. [33] indeed reported that in three different experiments, reducing $\mathrm{NO}_{3}{ }^{-}$concentration in the nutrient solution reduced lettuce nitrate content, and that the highest nitrate concentration occurred in the most external leaves of plants. Conversely, Amr and Hadidi [34] found that the growing cycle (autumn vs spring) had no effect on $\mathrm{NO}_{3}{ }^{-}$concentration of vegetables grown in a greenhouse.

As for lettuce yield, reducing fertilization during the final growing days in our autumn trial did not lead to a clear decrease in $\mathrm{NO}_{3}{ }^{-}$concentration, which was also contrary to our expectations. In some cases, an increase was even measured, although it was not statistically relevant. Instead, the $\mathrm{NO}_{3}{ }^{-}$ concentration during the spring trial across all cycle durations (25 DAT/30 DAT) showed that (i) stopping fertilization only 2 days before harvest may reduce $\mathrm{NO}_{3}{ }^{-}$concentration in leaves, and (ii) combining T6 treatment with the 27-DAT cycle is the most effective strategy to minimize $\mathrm{NO}_{3}{ }^{-}$concentration both on fresh and dry matter basis. This agrees with what suggested by Gonnella et al. [19] who found 
that the substitution of the nutrient solution with water 2 days before harvesting decreased nitrate concentration in lettuce leaves $(-17 \%)$.

\section{Conclusions}

The innovative production system used in this research (intermittent NFT) has been proved to be effective for the production of soilless lettuce, yield and nitrate concentration in leaves being optimized by reducing the fertilization rate in the final period of the growing cycle. The duration of 30 DAT resulted as the optimum both for autumn and spring cultivation in terms of fresh biomass yield. Although $\mathrm{NO}_{3}{ }^{-}$concentration in leaves was never affected by stopping $\mathrm{N}$ fertilization in the last days during the autumn growing cycle, the best trade-off in terms of biomass production and $\mathrm{NO}_{3}{ }^{-}$concentration in soilless lettuce was obtained by stopping fertilization in the last 2 days. Such a fertilization suspension before harvest in the spring trial did not reduce fresh biomass yield, but it mitigated $\mathrm{NO}_{3}{ }^{-}$accumulation by $29 \%$. Additionally, stopping fertilization 4 days before the spring harvest should be considered if reducing $\mathrm{NO}_{3}{ }^{-}$accumulation in leaves is the major objective $(-58 \%)$ and moderate yield penalties are acceptable $(-15 \%)$. Last but not least, stopping fertilization for 2 or 4 days at the end of the growing cycle leads to a $7-16 \%$ reduction in the total rate of fertilizers used, thus improving the ecological footprint of lettuce production.

Author Contributions: Conceptualization, V.T. and G.N.; methodology, V.T. and G.N.; formal analysis, S.S.; investigation, P.B. and A.F.; data curation, A.F., C.G. and P.B.; writing-original draft preparation, V.T., C.G. and R.B.; writing - review and editing, A.F. and R.B.; supervision, V.T.; funding acquisition, G.N. and V.T. All authors have read and agreed to the published version of the manuscript.

Funding: This research received no external funding.

Acknowledgments: We would like to thank Sempre Fresco S.r.l., the company that hosted the greenhouse experiment and made this study possible. We also thank colleagues, technicians and students from the Agronomy Group in the Department of Sustainable Crop Production (Università Cattolica del Sacro Cuore of Piacenza), for their assistance throughout the experiment process, and Rosanna M. Giammanco for language editing.

Conflicts of Interest: The authors declare no conflict of interest.

\section{Appendix A}

Table A1. Maximum levels of nitrates admitted in vegetables in the European Union.

\begin{tabular}{|c|c|c|}
\hline Food Item & \multicolumn{2}{|c|}{ Maximum Levels of Nitrates $\left(\mathrm{mg} \mathrm{NO} \mathrm{Ng}^{3}\right)$} \\
\hline 1.1 Fresh spinach (Spinacia oleracea L.) & & 3500 \\
\hline 1.2 Preserved, deep-frozen or frozen spinach & & 2000 \\
\hline \multirow{8}{*}{$\begin{array}{l}\text { 1.3 Fresh lettuce (Lactuca sativa L.) (protected and } \\
\text { open-grown lettuce) excluding lettuce listed in } \\
\text { point } 1.4\end{array}$} & Harvested 1st October to 31st & \\
\hline & March: & \\
\hline & - lettuce grown under cover & 5000 \\
\hline & - lettuce grown in the open air & 4000 \\
\hline & Harvested 1st April to 30th & \\
\hline & September: & \\
\hline & - lettuce grown under cover & 4000 \\
\hline & - lettuce grown in the open air & 3000 \\
\hline \multirow{2}{*}{ 1.4 "Iceberg"-type lettuce } & - lettuce grown under cover & 2500 \\
\hline & - lettuce grown in the open air & 2000 \\
\hline \multirow{3}{*}{$\begin{array}{l}1.5 \text { Rocket salad (Eruca sativa Mill., Diplotaxis sp., } \\
\text { Brassica tenuifolia L., Sisymbrium tenuifolium L.) }\end{array}$} & Harvested 1st October to & \\
\hline & 31st March & 7000 \\
\hline & $\begin{array}{l}\text { Harvested 1st April to } \\
\text { 30th September }\end{array}$ & 6000 \\
\hline $\begin{array}{l}\text { 1.6 Processed cereal-based foods and baby foods } \\
\text { for infants and young children }\end{array}$ & & 200 \\
\hline
\end{tabular}




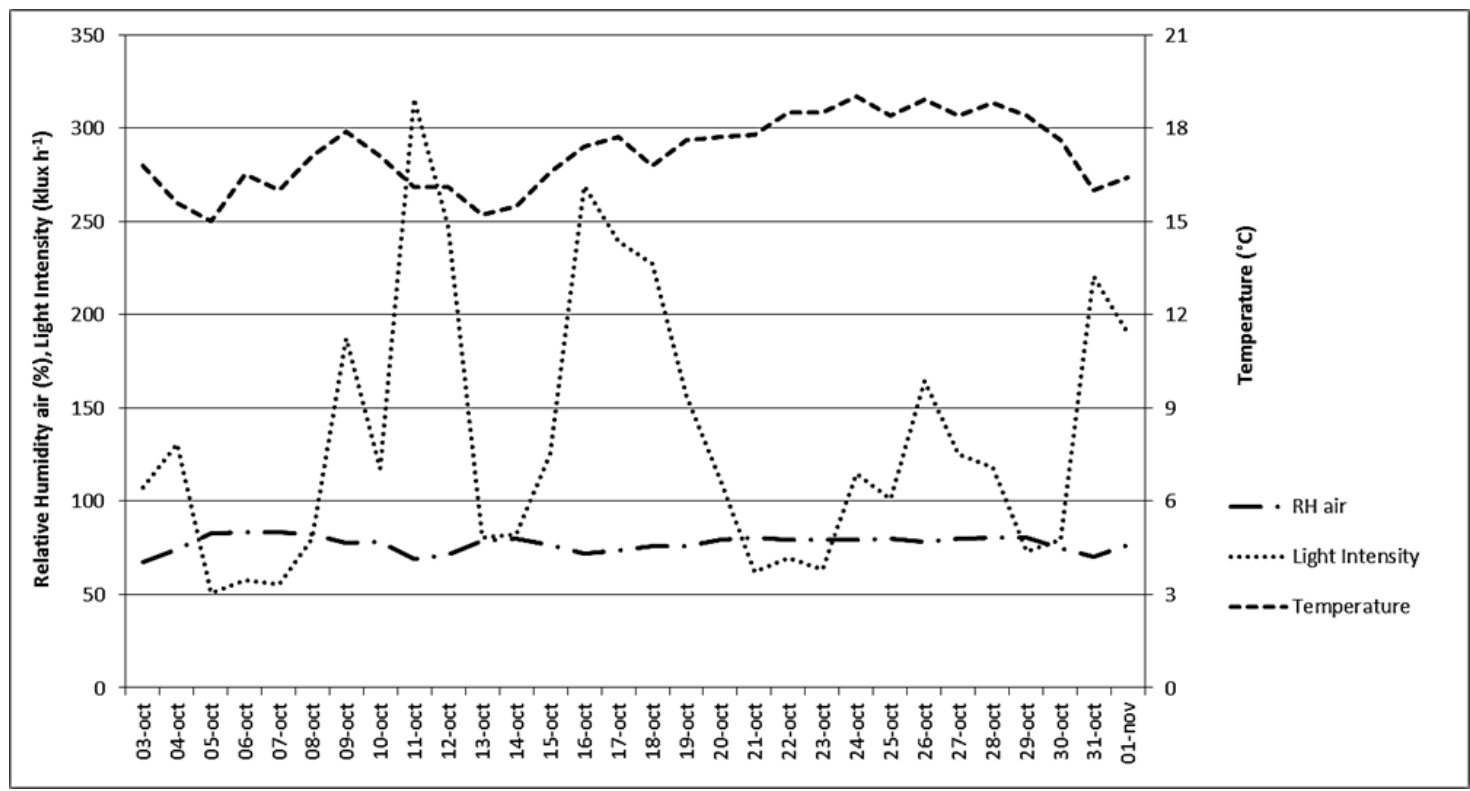

Figure A1. Greenhouse environmental conditions during the autumn lettuce growing cycle.

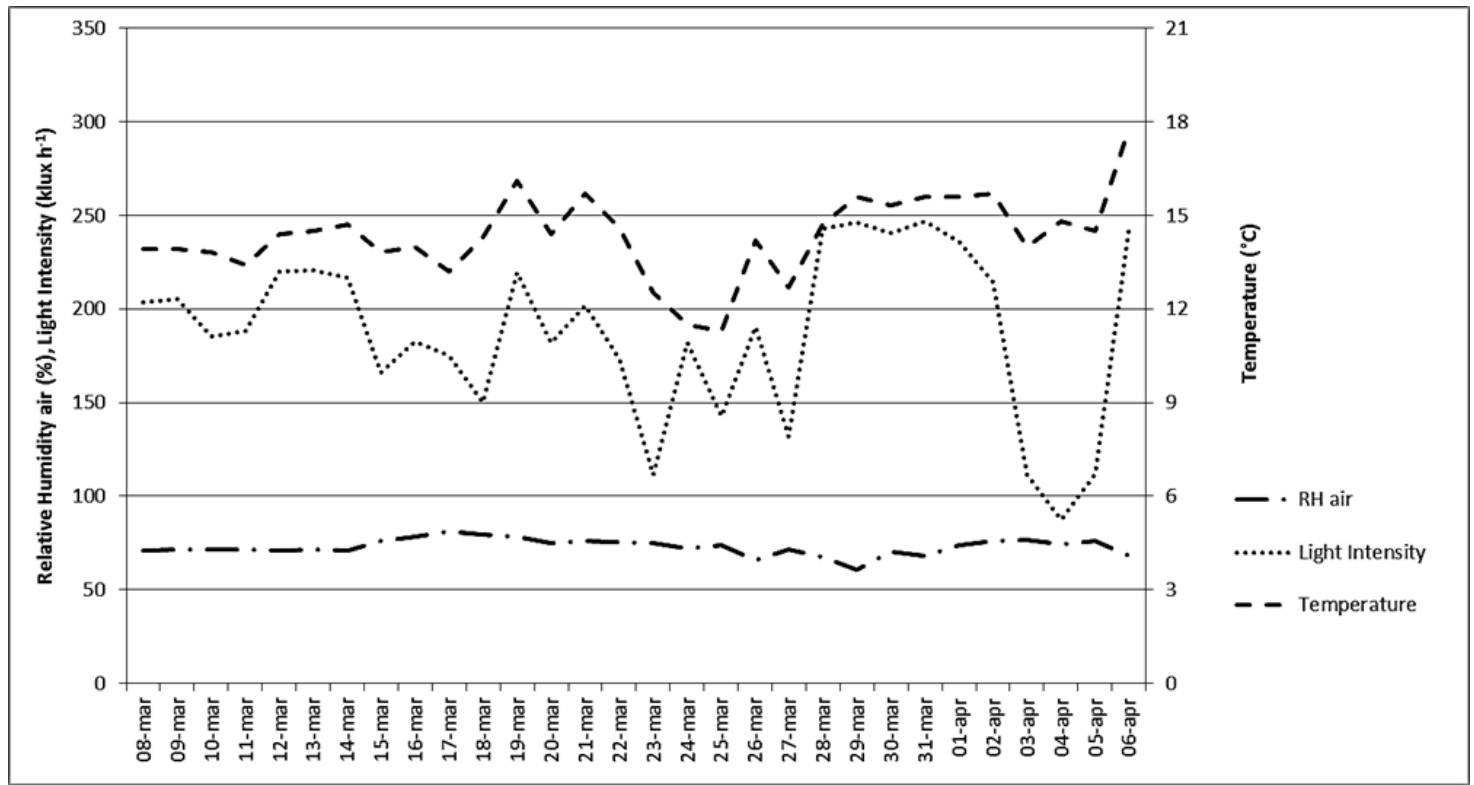

Figure A2. Greenhouse environmental conditions during the spring lettuce growing cycle.

\section{References}

1. Kř́stková, E.; Doležalová, I.; Lebeda, A.; Vinter, V.; Novotná, A. Description of morphological characters of lettuce (Lactuca sativa L.) genetic resources. Hortic. Sci. 2008, 35, 113-129. [CrossRef]

2. FAOSTAT_Food and Agriculture Organization of the United Nations, Statistics Division. Forestry Production and Trade. Available online: http://www.fao.org/faostat/en/\#data/FO (accessed on 4 April 2019).

3. Artés, F.; Allende, A. Minimal Fresh Processing of Vegetables, Fruits and Juices. In Emerging Technologies for Food Processing; Elsevier: London, UK, 2014; pp. 583-597. [CrossRef]

4. Kim, M.J.; Moon, Y.; Tou, J.C.; Mou, B.; Waterland, N.L. Nutritional value, bioactive compounds and health benefits of lettuce (Lactuca sativa L.). J. Food Compos. Anal. 2016, 49, 19-34. [CrossRef]

5. Kmecl, V.; Knap, T.; Žnidarčič, D. Evaluation of the nitrate and nitrite content of vegetables commonly grown in Slovenia. Ital. J. Agron. 2017, 12, 79-84. [CrossRef] 
6. Zandvakili, O.R.; Barker, A.V.; Hashemi, M.; Etemadi, F.; Autio, W.R.; Weis, S. Growth and nutrient and nitrate accumulation of lettuce under different regimes of nitrogen fertilization. J. Plant Nutr. 2019, 42, 1575-1593. [CrossRef]

7. Pinto, E.; Almeida, A.A.; Aguiar, A.A.; Ferreira, I.M.P.L.V.O. Comparison between the mineral profile and nitrate content of microgreens and mature lettuces. J. Food Compos. Anal. 2015, 37, 38-43. [CrossRef]

8. Fewtrell, L. Drinking-Water Nitrate, Methemoglobinemia, and Global Burden of Disease: A Discussion. Environ. Health Perspect. 2004, 112, 1371-1374. [CrossRef]

9. Salehzadeh, H.; Maleki, A.; Rezaee, R.; Shahmoradi, B.; Ponnet, K. The nitrate content of fresh and cooked vegetables and their health-related risks. PLoS ONE 2020, 15, e0227551. [CrossRef]

10. Manzocco, L.; Foschia, M.; Tomasi, N.; Maifreni, M.; Costa, L.D.; Marino, M.; Cortella, G.; Cesco, S. Influence of hydroponic and soil cultivation on quality and shelf life of ready-to-eat lamb's lettuce (Valerianella locusta L. Laterr). J. Sci. Food Agric. 2011, 91, 1373-1380. [CrossRef]

11. Liu, X.; Ardo, S.; Bunning, M.; Parry, J.; Zhou, K.; Stushnoff, C.; Stoniker, F.; Yu, L.(Lucy); Kendall, P. Total phenolic content and DPPH radical scavenging activity of lettuce (Lactuca sativa L.) grown in Colorado. LWT 2007, 40, 552-557. [CrossRef]

12. Escobar-Gutierrez, A.; Burns, I.G.; Lee, A.; Edmondson, R.N. Screening lettuce cultivars for low nitrate content during summer and winter production. J. Hortic. Sci. Biotechnol. 2002, 77, 232-237. [CrossRef]

13. Gruda, N. Do soilless culture systems have an influence on product quality of vegetables? J. Appl. Bot. Food Qual. 2009, 82, 141-147. [CrossRef]

14. Fallovo, C.; Rouphael, Y.; Rea, E.; Battistelli, A.; Colla, G. Nutrient solution concentration and growing season affect yield and quality of Lactuca sativa L. var. acephala in floating raft culture. J. Sci. Food Agric. 2009, 89, 1682-1689. [CrossRef]

15. Sago, Y.; Shigemura, A. Quantitative Nutrient Management Reduces Nitrate Accumulation in Hydroponic Butterhead Lettuces Grown under Artificial Lighting. HortScience 2018, 53, 963-967. [CrossRef]

16. Gromaz, A.; Torres, J.F.; Bautista, A.S.; Pascual, B.; López-Galarza, S.; Maroto, J.V. Effect of different levels of nitrogen in nutrient solution and crop system on nitrate accumulation in endive. J. Plant Nutr. 2017, 40, 2045-5053. [CrossRef]

17. Contam, E.P.O.C.I.T.F.C. Statement on possible public health risks for infants and young children from the presence of nitrates in leafy vegetables. EFSA J. 2010, 8, 1935. [CrossRef]

18. ISTAT (Italian National Institute of Statistics). Statistics for Agriculture. Available online: http://dati.istat.it/ Index.aspx (accessed on 24 June 2020).

19. Gonnella, M.; Serio, F.; Conversa, G.; Santamaria, P. Yield and Quality Of Lettuce Grown In Floating System Using Different Sowing Density And Plant Spatial Arrangements. Acta Hortic. 2003, 614, 687-692. [CrossRef]

20. Selma, M.V.; Luna, M.C.; Martínez-Sánchez, A.; Tudela, J.A.; Beltrán, D.; Baixauli, C.; Gil, M.I. Sensory quality, bioactive constituents and microbiological quality of green and red fresh-cut lettuces (Lactuca sativa L.) are influenced by soil and soilless agricultural production systems. Postharvest Boil. Technol. 2012, 63, 16-24. [CrossRef]

21. Nicola, S.; Fontana, E. Fresh-Cut Produce Quality. In Implications for a Systems Approach; Elsevier Inc.: Amsterdam, The Netherlands, 2014; ISBN 9780124081376.

22. Cros, V.; Martínez-Sánchez, J.J.; Franco, J.A. Good Yields of Common Purslane with a High Fatty Acid Content Can Be Obtained in a Peat-based Floating System. HortTechnology 2007, 17, 14-20. [CrossRef]

23. Burrage, S. Nutrient Film Technique in Protected Cultivation. Acta Hortic. 1993, 323, 23-38. [CrossRef]

24. Santamaria, P.; Elia, A.; Serio, F.; Todaro, E. A survey of nitrate and oxalate content in fresh vegetables. J. Sci. Food Agric. 1999, 79, 1882-1888. [CrossRef]

25. Guadagnin, S.G.; Rath, S.; Reyes, F.G.R. Evaluation of the nitrate content in leaf vegetables produced through different agricultural systems. Food Addit. Contam. 2005, 22, 1203-1208. [CrossRef] [PubMed]

26. Mahlangu, R.I.S.; Maboko, M.M.; Sivakumar, D.; Soundy, P.; Jifon, J. Lettuce (Lactuca sativaL.) growth, yield and quality response to nitrogen fertilization in a non-circulating hydroponic system. J. Plant Nutr. 2016, 39, 1766-1775. [CrossRef]

27. Burns, I.G.; Zhang, K.; Turner, M.K.; Edmondson, R. Iso-Osmotic Regulation Of Nitrate Accumulation In Lettuce. J. Plant Nutr. 2010, 34, 283-313. [CrossRef]

28. Delaide, B.; Goddek, S.; Gott, J.; Soyeurt, H.; Jijakli, M.H. Lettuce (Lactuca sativa L. var. Sucrine) Growth Performance in Complemented Aquaponic Solution Outperforms Hydroponics. Water 2016, 8, 467. [CrossRef] 
29. Tei, F.; Benincasa, P.; Guiducci, M. Critical Nitrogen Concentration in Lettuce. Acta Hortic. 2003, 627, $187-194$. [CrossRef]

30. Di Gioia, F.; Gonnella, M.; Buono, V.; Ayala, O.; Santamaria, P. Agronomic, physiological and quality response of romaine and red oak-leaf lettuce to nitrogen input. Ital. J. Agron. 2017, 12, 47-58. [CrossRef]

31. Lopes, S.J.; Neto, D.D.; Manfron, P.A.; Jasniewicz, L.R. Models to estimate phytomass accumulation of hydroponic lettuce. Sci. Agricola 2004, 61, 392-400. [CrossRef]

32. Tamme, T.; Reinik, M.; Roasto, M.; Juhkam, K.; Tenno, T.; Kiis, A. Nitrates and nitrites in vegetables and vegetable-based products and their intakes by the Estonian population. Food Addit. Contam. 2006, 23, 355-361. [CrossRef]

33. Marsic, N.K. Effects of different nitrogen levels on lettuce growth and nitrate accumulation in iceberg lettuce (Lactuca sativa var. capitata L.) grown hydroponically under greenhouse conditions. Gartenbauwissenschaft 2002, 67, 128-134.

34. Amr, A.; Hadidi, N. Effect of Cultivar and Harvest Date on Nitrate (NO3) and Nitrite (NO2) Content of Selected Vegetables Grown Under Open Field and Greenhouse Conditions in Jordan. J. Food Compos. Anal. 2001, 14, 59-67. [CrossRef]

(C) 2020 by the authors. Licensee MDPI, Basel, Switzerland. This article is an open access article distributed under the terms and conditions of the Creative Commons Attribution (CC BY) license (http://creativecommons.org/licenses/by/4.0/). 